\title{
Anabolic-androgenic steroid dependence: an emerging disorder
}

\author{
Gen Kanayama', Kirk J. Brower', Ruth I. Wood ${ }^{3}$, James I. Hudson' \& Harrison G. Pope Jr' \\ Biological Psychiatry Laboratory, McLean Hospital, Belmont, Massachusetts, and Department of Psychiatry, Harvard Medical School, Boston, MA, USA,' University \\ of Michigan Addiction Research Center, Ann Arbor, MI, USA² and Department of Cell and Neurobiology, Keck School of Medicine of the University of Southern \\ California, Los Angeles, CA, USA
}

\section{ABSTRACT}

Aims Anabolic-androgenic steroids (AAS) are widely used illicitly to gain muscle and lose body fat. Here we review the accumulating human and animal evidence showing that AAS may cause a distinct dependence syndrome, often associated with adverse psychiatric and medical effects. Method We present an illustrative case of AAS dependence, followed by a summary of the human and animal literature on this topic, based on publications known to us or obtained by searching the PubMed database. Results About 30\% of AAS users appear to develop a dependence syndrome, characterized by chronic AAS use despite adverse effects on physical, psychosocial or occupational functioning. AAS dependence shares many features with classical drug dependence. For example, hamsters will selfadminister AAS, even to the point of death, and both humans and animals exhibit a well-documented AAS withdrawal syndrome, mediated by neuroendocrine and cortical neurotransmitter systems. AAS dependence may particularly involve opioidergic mechanisms. However, AAS differ from classical drugs in that they produce little immediate reward of acute intoxication, but instead a delayed effect of muscle gains. Thus standard diagnostic criteria for substance dependence, usually crafted for acutely intoxicating drugs, must be adapted slightly for cumulatively acting drugs such as AAS. Conclusions AAS dependence is a valid diagnostic entity, and probably a growing public health problem. AAS dependence may share brain mechanisms with other forms of substance dependence, especially opioid dependence. Future studies are needed to characterize AAS dependence more clearly, identify risk factors for this syndrome and develop treatment strategies.

Keywords Anabolic steroids, androgens, men, performance-enhancing drugs, substance abuse, substance dependence, testosterone.

Correspondence to: Harrison G. Pope Jr, McLean Hospital, Belmont, MA 02178, USA. E-mail: hpope@mclean.harvard.edu Submitted 6 April 2009; initial review completed 2 June 2009; final version accepted 2 July 2009

\section{INTRODUCTION}

The anabolic-androgenic steroids (AAS) are a family of lipophilic hormones derived from cholesterol that includes the natural male hormone, testosterone, together with numerous synthetic testosterone derivatives [1]. By ingesting supraphysiological doses of these hormones, in combination with intensive weightlifting and appropriate nutrition, AAS users can greatly increase their muscle mass, often well beyond the limits attainable by natural means [2]. For decades, elite athletes have used AAS to improve performance [3]. Today, however, most AAS users are not competitive athletes, but simply individuals who want to look leaner and more muscular [1,4-8]. As we have explained in detail else- where [9], this much larger but less visible population of illicit AAS users began to emerge in the 1980s-a trend stimulated in part by the appearance of progressively more sophisticated underground guides on how to selfadminister AAS [10-14]. Western cultural developments also probably contributed to the increased prevalence of use of AAS, as media images focused increasingly on male muscularity [15-18]. Over the last few decades, even children's action toys, such as 'GI Joe' in America and 'Action Man' in the British Commonwealth, have begun to acquire the bodies of AAS users [19]. Perhaps as a result of these trends, illicit AAS use has now grown into a widespread form of substance abuse throughout western societies, including the United States [20-22], British Commonwealth countries [23-25], Scandinavian 
countries [26-28] and others [25,29-31]. Although epidemiological studies in these various countries have produced a wide range of prevalence estimates, most have reported a life-time prevalence of AAS use of at least 3\% in young men, suggesting that some tens of millions of individuals world-wide have used these drugs. By contrast, AAS use in women is uncommon, as women are less likely to want to become very muscular and are also vulnerable to the masculinizing effects of AAS, such as beard growth, deepening of the voice and masculinized sexual characteristics [32-35].

AAS users generally self-administer their drugs for blocks of time, called colloquially 'cycles'. Cycles typically last 8-16 weeks, separated by drug-free intervals lasting months or years [36,37]. Planned cycles of increasing and decreasing AAS doses ('pyramiding') allow users to avoid plateauing (developing tolerance), minimize withdrawal symptoms at the end of a cycle and conserve drug supplies [38]. Perhaps the most important rationale for cycles, however, is the fact that exogenous AAS administration suppresses the hypothalamic-pituitary-testicular (HPT) axis, leading to decreased endogenous testosterone production in men $[39,40]$. If a man uses AAS in cycles, rather than continuously, then the HPT axis can rebound during the drug-free intervals between cycles, restoring normal endogenous testosterone production.

Many individuals use only a few cycles of AAS in their careers, with a cumulative life-time exposure of less than 12 months [36,37]. Such individuals often report few, if any, adverse medical or psychological effects from AAS $[41,42]$. On the other hand, some individuals progress from discrete cycles of AAS into a pattern of nearly unbroken use, which may continue despite prominent adverse medical, psychological and social effects [43]. This syndrome of AAS dependence has been recognized for more than 20 years; it appears to be common and possibly increasing in prevalence, as explained below, but much in need of further study [1]. Here we attempt to summarize current knowledge on AAS dependence. We begin with an illustrative case of AAS dependence, then review the accumulating human and animal literature on this topic, compare AAS dependence with classical drug dependence and suggest avenues for future research. This review is based on publications known to us, a search of publications involving 'anabolic steroids' in the PubMed database and additional publications referenced in these articles.

\section{CASE EXAMPLE}

Mr A, currently 34 years old, grew up in an uppermiddle-class professional family in South Florida. He reported no major social or academic problems prior to adolescence, but by age 17 developed alcohol and nico- tine dependence, soon followed by polysubstance dependence involving marijuana, hallucinogens, alcohol and cocaine, depending on which drugs were available. At age 19 he was admitted to a detoxification facility, and thereafter remained abstinent from 'classical' drugs of abuse for the next 3 years. During this period, however, he began regular weightlifting in the gym, acquired AAS-using friends, and soon began to use AAS himself, starting with cycles of 12-16 weeks in duration, separated by drug-free intervals of 4-8 weeks. Like his AASusing friends, Mr A became focused on his muscularity and often felt that he was still not big enough, despite his objective gains. He increased his doses of AAS over the next several years, reaching a maximum weekly dose of $500 \mathrm{mg}$ of injectable testosterone esters, combined with $400 \mathrm{mg}$ of injected nandrolone decanoate, plus $50 \mathrm{mg}$ of oral methenolone per day - a total dose equivalent to more than 20 times normal male endogenous testosterone production [44]. He gained some $25 \mathrm{~kg}$ of muscle over the course of the first 2 years; during this time he reported increased self-confidence and mild irritability, but no major adverse psychiatric or medical effects.

At age 22, Mr A relapsed into use of classical drugs and developed opioid and cocaine dependence, reaching doses of $300 \mathrm{mg}$ of OxyContin (long-acting oxycodone) per day. He continued to take AAS intermittently during this period. He underwent three detoxification admissions for opioid dependence over the next 4 years, and stopped using all classical drugs of abuse (including alcohol) successfully by age 26 . By the age of 32 , he also stopped smoking cigarettes. However, he has continued to use AAS steadily from age 26 to the present. During the first part of this interval $\mathrm{Mr}$ A still discontinued AAS for several weeks between cycles, but since age 31 he has been taking AAS virtually without interruption. He reports that if he stops using AAS, he quickly develops prominent fatigue, loss of sex drive and depressed mood. Therefore, he maintains carefully a sufficient supply of AAS to allow uninterrupted use.

$\mathrm{Mr}$ A now uses lower doses of AAS than when younger, with an average weekly dose of about 400$600 \mathrm{mg}$ of testosterone or equivalent. He currently displays several apparent adverse AAS effects, including bilateral gynecomastia and a recent fasting total cholesterol/high-density lipoprotein (HDL) ratio of 18.6 (normal less than 5.0). Mr A expresses concern about these effects, but is reluctant to discontinue or reduce AAS because he fears 'losing size'. He spends several hours per day at the gym, where he has many friends, most of whom are also AAS users. He has worked as a personal trainer for some time in a local health club, then at a store selling sports supplements such as protein powders and creatine. His life remains centered around 
the gym and the weightlifting culture, often to the exclusion of other social or occupational opportunities.

\section{HUMAN STUDIES}

\section{Initial reports and case series, 1988-1990}

Mr A's history resembles that of other cases of AAS dependence reported previously. This literature began to appear in the late 1980s, starting with individual case reports describing AAS users who took the drugs initially to gain muscle for bodybuilding, but who went on to develop depression whenever they discontinued AAS use [45-47]. Interestingly, one of these individuals exhibited symptoms resembling opiate withdrawal when challenged with naloxone, although he had no apparent history of opiate use-an observation suggesting that AAS dependence might be associated with opioid-type features [45]. In the first published case series, Brower et al. [48] described eight AAS users with apparent dependence; all these men met two of the DSM-III-R criteria [49] for substance dependence, summarized as 'continued substance use despite problems caused or worsened by use' and 'withdrawal symptoms'. However, users varied with regard to the other DSM-III-R substance dependence criteria, many of which were designed for acutely intoxicating drugs, and which were therefore not well suited for drugs such as AAS that produce little acute intoxication.

\section{Studies using DSM-III-R and DSM-IV criteria, 1991-2005}

Several subsequent studies in the United States, United Kingdom and Australia ([50-54]; Table 1) have also attempted to diagnose AAS dependence using the DSMIII-R [49] or DSM-IV [55] criteria for substance dependence, despite the difficulties of adapting these criteria to a non-intoxicating drug. Of 426 AAS users across these five studies, 144 (33.8\%) met DSM-IV criteria for dependence, as the study authors interpreted these criteria for the case of AAS. As in the case series above, withdrawal was the criterion met most commonly, whereas 'frequent intoxication or withdrawal symptoms when expected to function' was rare, as might be expected. A sixth study, using the Structured Clinical Interview for DSM-III-R (SCID) [56], reported dependence in $10(14 \%)$ of 71 current or past male AAS users and one (17\%) of six female AAS users ([57] and D. A. Malone, personal communication, January 2009). Finally, a seventh study, also using the SCID, reported a life-time history of AAS dependence in approximately 22 (25\%) of 88 male AAS users [37]. However, these latter two studies did not specify the number of AAS users meeting each individual DSM-IV substance dependence criterion in the manner of the studies summarized in Table 1.

It should be recognized that the above studies are naturalistic studies of AAS users recruited in the field from gymnasiums $[37,50-53,57]$ or via the internet [54]. Like all naturalistic studies of illicit substance abusers, these studies are potentially vulnerable to various forms of bias $[58,59]$. For example, dependent AAS users may have been either more or less likely to agree to participate in these studies than non-dependent AAS users or AAS non-users, resulting in selection bias. Information bias may have resulted if respondents failed to disclose that they had used AAS, or failed to report adverse or undesirable outcomes associated with AAS use. Confounding variables, such as premorbid attributes of AAS users or concomitant use of other substances, may have also influenced observed associations. However, because human AAS dependence cannot, ethically, be studied prospectively under laboratory conditions, these field studies currently represent our best available evidence regarding this syndrome.

\section{The prevalence of AAS dependence}

Collectively, the above seven studies suggest that about $30 \%$ of illicit AAS users develop dependence - although it must be remembered that this estimate might be influenced by selection bias. For example, individuals who had experimented only briefly with AAS might be underrepresented in samples recruited from gymnasiums, causing the studies to overestimate the prevalence of AAS dependence. In any event, however, there is reason to suspect that the prevalence of clinically significant AAS dependence may be increasing. This impression is based on the observation that the mean age of onset of AAS dependence in the above studies appears to be in the late 20s. Therefore, adverse psychiatric and medical effects of prolonged AAS dependence would probably not surface until age 30 or later [1,9]. When it is considered that illicit AAS use did not become widespread until the 1980s, as discussed above, it follows that within the subgroup of AAS users who have developed chronic use, many are only now growing old enough to show clinically significant AAS dependence. Therefore, as new waves of recent younger AAS users reach their 30 s and 40 s, the prevalence of AAS dependence may continue to rise.

We can illustrate the above considerations using prevalence data on male AAS users in the United States. American surveys over the last 20 years have estimated that $3-11 \%$ of male high school students have used AAS [5,21,60-64]. We have suggested elsewhere that some of these estimates may be too high [35] — but even using the lowest figure of $3 \%$, it would follow that over the last 20 


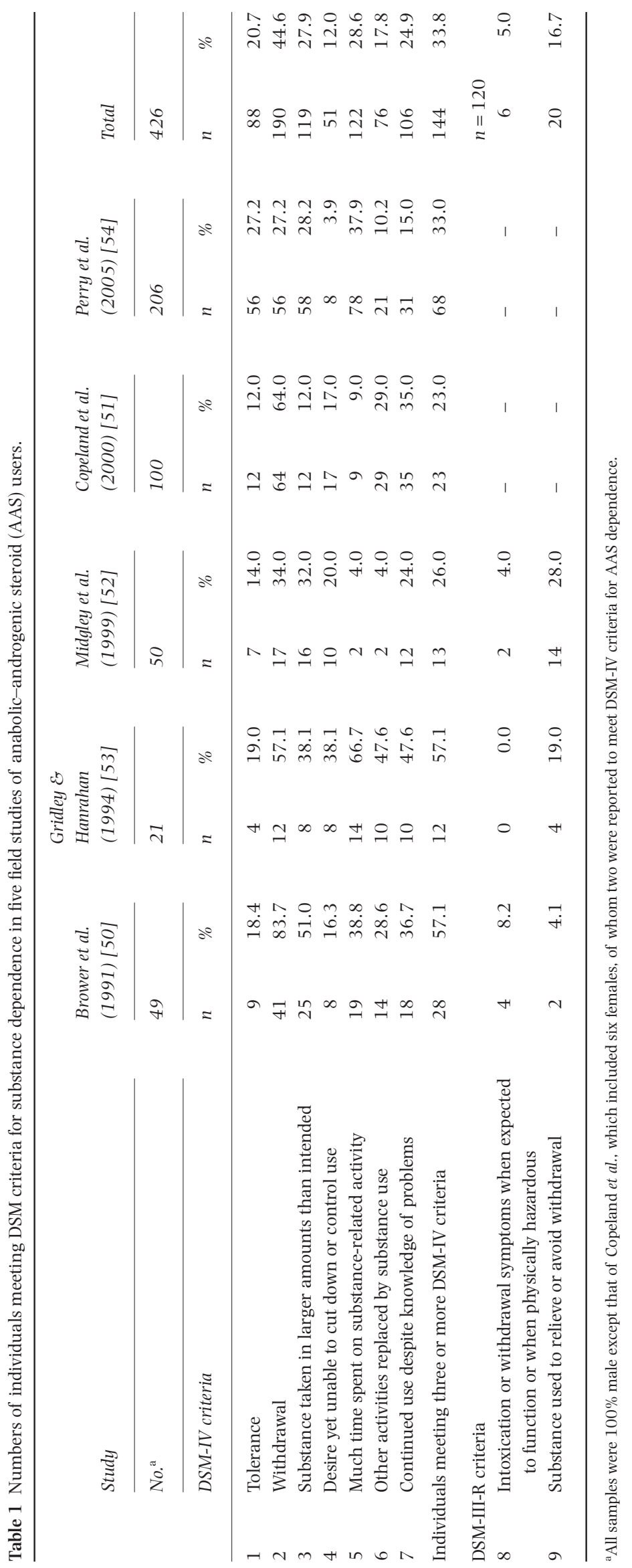


years, more than 1 million American boys initiated AAS use as teenagers. Furthermore, as the median age of onset of initial AAS use in the United States appears to be considerably older than age 19 [35,36], one must add to this figure at least another million American men in the last two decades who first initiated AAS use after the age of 19. About half of this 20-year cohort of American AAS users is still under age 30 today. If we estimated conservatively that the risk of AAS dependence among these men was only $14 \%$ - the lowest figure reported among the seven studies above-it would still follow that in the United States alone there are hundreds of thousands of still-young chronic AAS users who are only now approaching the age where they may show clinically significant AAS dependence. Chronologically, most other western countries probably lag the United States in the onset of widespread AAS use-placing them earlier on this possible curve of rising AAS dependence.

\section{Features of AAS dependence}

Despite the substantial prevalence of AAS dependence, little is known about the features of AAS-dependent individuals. Several studies have noted that dependent users consumed significantly more AAS than non-dependent users, as measured by total dose [50], number of different AAS taken simultaneously [53], total number or length of AAS cycles $[50,51,54]$ or cumulative duration of AAS use [53]. When demographic correlates of dependent use were assessed [50,51], however, no differences between dependent and non-dependent users were found. Two studies reported a significantly greater likelihood of either aggressive symptoms [50] or 'roid rage' [51] in dependent versus non-dependent users. However, none of the studies in Table 1 assessed life-time psychiatric disorders systematically in user groups.

One new study has recently assessed demographic variables and life-time psychiatric disorders in men with AAS dependence $(n=20)$ compared to non-dependent AAS users $(n=42)$ and AAS non-users $(n=72)$ [8]. In this study, non-dependent AAS users exhibited virtually no significant differences from non-users on any of a wide range of demographic variables or life-time psychiatric diagnoses, whereas the dependent AAS users differed markedly from both comparison groups on a number of measures. Specifically, dependent AAS users were significantly older and more muscular than the other groups; more likely to have had a single parent by age 13; more likely to report a first-degree relative with a substance use disorder; and less well educated. Dependent AAS users also reported a much more frequent history of conduct disorder than non-dependent AAS users and a much higher life-time prevalence of non-alcohol substance dependence than either comparison group; the latter dif- ferences were driven largely by a strikingly higher prevalence of opioid abuse and dependence-an important finding that we discuss in more detail in the following paragraphs.

\section{The association of AAS dependence with opioid dependence}

Several reports have suggested that AAS dependence might share features with opioid dependence in humans. As early as 1989, Kashkin \& Kleber hypothesized that AAS dependence might arise in part via an opioidergic mechanism, in which AAS might potentiate central endogenous opioid activity and where AAS withdrawal would lead to a decrease in this activity and a subsequent acute hyperadrenergic syndrome [65]. This hypothesized link between AAS and opioids would seem consistent with a number of human observations including (i) the 'opioidtype features' described in the case report of AAS dependence cited above [45]; (ii) the observation that AAS users seem to be particularly at risk for developing opioid abuse or dependence [66-68]; (iii) the converse finding that men with opioid dependence were more likely to report prior AAS use than men with other forms of substance dependence [69]; and (iv) a post-mortem study of Swedish AAS users, reporting that AAS appeared to reduce the threshold for heroin overdose [70].

The recent field study described above adds further evidence for a relationship between AAS and opioids [8]. Ten $(50 \%)$ of the dependent AAS users in this study met DSM-IV criteria for a life-time history of opioid abuse or dependence, compared to eight (19\%) non-dependent AAS users [odds ratio 6.7; $(1.5,231) ; P=0.015$ ] and five (7\%) non-users [16.3 (3.4, 78.9); $P=0.001]$. Among the various men with AAS dependence, opioid abuse or dependence began both before and after the onset of AAS use, suggesting the possibility that these forms of substance use might arise from a common diathesis.

\section{ANIMAL STUDIES}

Animal studies offer extensive additional evidence that AAS can induce dependence, and further support a link between the actions of AAS and opioids [71]. In humans, it is difficult to separate the direct rewarding effects of AAS from the secondary rewards of increased muscularity and fitness. However, using conditioned place preference and self-administration models of reward, studies in animals have demonstrated that AAS are rewarding in a context where athletic performance is irrelevant. Rats and mice will choose to spend time in an environment where they have previously received AAS [72,73]. Hamsters will self-administer testosterone, including direct intracranial injections to the point of death, and they 
develop a syndrome of high-dose testosterone intoxication with opioid-like features [74]. Moreover, this syndrome is antagonized by naltrexone, and naltrexone pretreatment will prevent testosterone self-administration [75]. Not all animal species, however, appear to selfadminister AAS [76].

Animal studies also suggest that AAS modify brain opioid systems. For example, chronic nandrolone treatment in rats increased levels of endogenous opioids and their receptors in select limbic regions, including a 20-fold increase in beta-endorphin in the ventral tegmental area [77], as well as a selective reduction in dynorphin $\mathrm{b}$ in the nucleus accumbens [78]. Other studies in rats [79] and mice [80] have also shown that AAS may act by altering levels of opioid receptors. Actions of AAS to inhibit activity of the dynorphin/kappa opioid receptor system in the nucleus accumbens are particularly intriguing. Treatment with kappa receptor antagonists in the nucleus accumbens produces anxiolytic and antidepressant effects [81,82], similar to the effects of AAS [83]. The AAS-induced reduction in nucleus accumbens dynorphin might also facilitate dopaminergic activity [78]. However, it is notable that, unlike many other drugs of abuse, AAS do not stimulate dopamine release acutely in the nucleus accumbens [84]. This is consistent with the relatively slow time-course of AAS action, and may account for the absence of acute intoxicating effects.

Studies using the opioid antagonist naloxone have yielded variable results in AAS-treated animals. Nandrolone pretreatment enhanced withdrawal symptoms to naloxone in morphine-dependent mice [80], and naloxone reversed testosterone-induced locomotor depression in hamsters [75]. However, naloxone produced virtually no effects in three rhesus monkeys exposed to 2 weeks of high-dose testosterone [85]. It may be that testosterone serves as a partial opioid agonist, while also acting through several other non-opioid neurotransmitter systems. Specifically, AAS display important modulatory effects on serotonin [86-92], norepinephrine [89], dopamine [93-101] and gammaamino-butyric acid [93,100,102,103]. Animal studies have also shown that AAS modulate the effects of other drugs of abuse, such as central nervous system stimulants [104], cannabis [105] and alcohol [78,87]. Finally, androgen withdrawal is also probably a complex phenomenon that shares multiple mechanisms with other endocrine withdrawal syndromes and with withdrawal from drugs of abuse-including changes in opioid peptide systems, the mesolimbic dopaminergic system and other central pathways [106]. Although a full discussion of this literature is beyond the scope of the present paper, several recent reviews have addressed in greater detail the interactions of AAS with various neurotransmitter systems and with other drugs $[71,93,101]$.

\section{AAS DEPENDENCE VERSUS 'CLASSICAL' DRUG DEPENDENCE}

As illustrated in the above sections, AAS show both similarities and differences when compared to classical drugs of abuse (Table 2). Similarities include a characteristic

Table 2 Similarities and differences between anabolic-androgenic steroids (AAS) and classical drugs of abuse.

\begin{tabular}{|c|c|}
\hline Classical drugs & $A A S$ \\
\hline \multicolumn{2}{|l|}{ Similarities } \\
\hline Animals will self-administer many classical drugs & Hamsters will self-administer AAS \\
\hline Withdrawal syndrome after prolonged use of many drugs & Characteristic withdrawal syndrome after prolonged use \\
\hline $\begin{array}{l}\text { Individuals often continue drug use despite adverse } \\
\text { medical and psychological effects }\end{array}$ & Use may be continued despite adverse effects \\
\hline Distinct subculture surrounding use of the drug & Well-established subculture involving the gym and body image \\
\hline Polydrug use common & AAS users frequently abuse other drugs \\
\hline \multicolumn{2}{|l|}{ Differences } \\
\hline Immediate reward from intoxicating effect & $\begin{array}{l}\text { No immediate intoxication, but may cause increased energy, } \\
\text { libido, and self-confidence in addition to delayed muscular gains }\end{array}$ \\
\hline $\begin{array}{l}\text { Frequent residual adverse effects from intoxication } \\
\text { (hangovers, sleep disruption, acute withdrawal } \\
\text { depression, etc.) }\end{array}$ & Few immediate adverse effects \\
\hline Frequently impairs performance (work, driving, etc.) & $\begin{array}{l}\text { Minimal performance impairment, although irritability, aggression, } \\
\text { and mood swings may impair social relationships }\end{array}$ \\
\hline Physiological tolerance develops to many drugs & $\begin{array}{l}\text { Limited evidence for physiological tolerance, although users may } \\
\text { intentionally increase doses to increase effects }\end{array}$ \\
\hline $\begin{array}{l}\text { Time-consuming (obtaining drug, intoxication, } \\
\text { recovery from intoxication) }\end{array}$ & $\begin{array}{l}\text { No acute intoxication, so that drug use per se is rarely } \\
\text { time-consuming }\end{array}$ \\
\hline
\end{tabular}


withdrawal syndrome, self-administration by animals as just discussed, continued use despite adverse effects, maladaptive behavioral patterns surrounding use, and comorbid abuse of other substances, as illustrated by the case of $\mathrm{Mr} \mathrm{A}$ and in various reports in the literature [8,9,21,36,62,63,69,107-111]. Unlike classical drugs of abuse, however, AAS produce no immediate reward in the form of acute intoxication. In one study, for example, abstinent heroin users could readily distinguish single injections of morphine as rewarding, whereas injections of testosterone or placebo were not perceived as rewarding [112]. Although AAS may produce some feelings of euphoria and increased self-confidence, these effects are inconsistent, slow to develop, and usually immaterial in the decision to use the drugs [59]. Also, as they are not acutely intoxicating, AAS rarely compromise performance or cause acute adverse effects in the manner of drugs such as cocaine or alcohol.

This fact may explain why individuals with AAS dependence appear less likely to seek treatment than individuals with many forms of classical drug dependence, who often seek treatment because of impaired occupational function, complaints from significant others or subjective distress [113]. In addition, some data suggest that AAS users may also be reluctant to seek treatment because they distrust health professionals and doubt that such professionals have sufficient knowledge of AAS [114]. Several authors have commented on the need for professionals to become more familiar with AAS in response to these problems $[113,115,116]$.

Given the slow time-course of AAS effects and the absence of acute intoxication, standard substancedependence criteria, such as those of DSM-IV [55] or ICD-10 [117], do not fit AAS dependence precisely, because these criteria were generally crafted to apply primarily to acutely intoxicating drugs. However, as illustrated in a recent publication (see Table 3), the DSM-IV criteria can be adapted easily with minor modifications to capture the maladaptive features of AAS dependence [118].

It should be noted that nicotine dependence, like AAS dependence, also differs from classical drug dependence, because few users smoke tobacco for its acute intoxicating effects [119]. Indeed, in contrast to the other categories of substances, a diagnosis of nicotine intoxication does not appear in DSM-IV. Unlike nicotine dependence, however, which rarely impairs psychological or social functioning, AAS dependence is similar to other drugs of dependence in terms of its potential adverse behavioral outcomes, such as impaired interpersonal functioning and substance-induced mood disorders [43].

In the United States, most prescription drugs with abuse potential are classed as Schedules II, III or IV substances under the jurisdiction of the Drug Enforcement
Table 3 DSM substance dependence criteria interpreted for diagnosing anabolic-androgenic steroids (AAS) dependence (from Kanayama et al. [118]).

A maladaptive pattern of anabolic-androgenic steroids (AAS) use,

leading to clinically significant impairment or distress, as manifested by three (or more) of the following, occurring at any time in the same 12-month period:

1 Tolerance, as defined by either of the following:

(a) a need for markedly increased amounts of the substance to achieve intoxication or desired effect; for AAS this progression to markedly larger doses may be related to dissatisfaction with the previous level of desired effect (e.g. level of muscle mass)

(b) markedly diminished effect with continued use of the same amount of the substance (e.g. failure to maintain the same level of lean muscle mass on a given dose of AAS)

2 Withdrawal, as manifested by either of the following:

(a) a characteristic withdrawal syndrome, characterized for AAS by two or more of the following features: depressed mood, prominent fatigue, insomnia or hypersomnia, decreased appetite and loss of libido

(b) AAS are used to relieve or avoid withdrawal symptoms

3 The substance is often taken in larger amounts or over a longer period than was intended. For AAS, this may be manifested by repeatedly resuming courses of AAS use after a shorter 'off' period than the individual had originally planned, or by eliminating 'off' periods entirely

4 There is a persistent desire or unsuccessful efforts to cut down or control substance use. For AAS, this may be manifested by unsuccessful attempts to reduce or stop AAS use because of prominent anxiety about losing perceived muscular size

5 A great deal of time is spent in activities necessary to obtain the substance, use the substance or recover from its effects. For AAS, this may be manifested by extensive time spent participating in muscle-related activities surrounding AAS use (e.g. time spent in weight training, attending to diet and supplement use and associating with other AAS users) in addition to actual time spent obtaining and administering AAS

6 Important social, occupational, or recreational activities are given up or reduced because of substance use. For AAS, this may be manifested by giving up important outside activities because of an extreme preoccupation with maintaining a supraphysiological AAS-induced level of muscularity (e.g. the individual relinquishes outside activities for fear that these activities will cause him to miss workouts, violate dietary restrictions, or compromise his ability to use of AAS)

7 The substance use is continued despite knowledge of having a persistent or recurrent physical or psychological problem that is likely to have been caused or exacerbated by the substance. For AAS, this includes medical problems such as gynecomastia, sexual dysfunction, hypertension, dyslipidemia and cardiomyopathy; or psychological problems such as dysphoric mood swings, severe irritability or increased aggressiveness 
Administration [120]. AAS are presently classed in Schedule III; interestingly, they represent the only class of substances in Schedules II or III that is not already recognized specifically in DSM-IV as causing a dependence syndrome [118]. Unlike most other scheduled drugs, however, AAS are available legally over the counter in many countries, and they can be ordered easily over the internet from overseas, making enforcement and interdiction difficult in countries where AAS are illegal [121].

\section{WHAT CAUSES AAS DEPENDENCE?}

In conclusion, why do some $30 \%$ of AAS users progress from more benign casual AAS use to more chronic and malignant AAS dependence, while 70\% do not? Unfortunately, as discussed above, current knowledge of human AAS dependence remains limited-indeed, arguably more limited than for any other major form of substance dependence. However, several hypotheses deserve consideration. First, the progression to AAS dependence might be catalyzed by body image disorders such as 'muscle dysmorphia' [17]—a form of body dysmorphic disorder, sometimes called 'reverse anorexia nervosa', characterized by preoccupations that one does not look sufficiently muscular [8,36,122-129]. Individuals with muscle dysmorphia may develop a maladaptive pattern of chronic AAS use because, paradoxically, they often become increasingly dissatisfied with their muscularity despite growing bigger on AAS $[69,123]$. However, this hypothesis remains uncertain. In an analysis of preliminary data from an ongoing study of AAS users conducted by three of the present authors (see [8]), it appears that adolescent body image disorder is associated strongly with initiation of AAS use. However, among AAS users, those who progressed to AAS dependence did not show a greater level of body image disturbance than those who did not. In other words, concerns about muscularity may bring an individual to the threshold of initially using AAS, but beyond this effect these concerns may not determine whether that individual progresses onward to AAS dependence (G. Kanayama, J. I. Hudson \& H. G. Pope Jr, 2009, unpublished data).

A second possible hypothesis is that individuals who progress to AAS dependence are more biologically vulnerable to the dysphoric effects of AAS withdrawal. As noted, AAS produce a characteristic withdrawal syndrome, with both affective and hypogonadal symptoms [65,130-132]. Individuals with more severe withdrawal symptoms after initial cycles of AAS use might become increasingly prone to resume AAS to prevent these symptoms. As implied above, this possible biological vulnerability might be related to the HPT axis, to opioidergic pathways or to other neurotransmitter mechanisms.
A third possible hypothesis is suggested by the apparent overlap of AAS dependence with other forms of substance dependence and with conduct disorder. An evolving neuropsychological literature has shown that individuals with many other forms of substance dependence exhibit a cluster of cognitive attributes that might be summarized as 'risk-taking/decision-making deficits', such as elevated rates of delay discounting [133,134]; increased impulsivity [135-137]; and deficits in decisionmaking, as illustrated by performance on gambling tasks and other measures of risk-taking [135,138-140]. These deficits are also associated with antisocial or 'psychopathic' traits [141-144], including conduct disorder [145-147]. Conduct disorder in turn appears to be associated with AAS dependence [8], and other studies have documented criminality and so-called Cluster B personality traits, including antisocial personality, among AAS users [121,148-155]. These features may, collectively, mark an endophenotype [156] that plays a causal role in the development of substance dependence [135]. With AAS, the direction of causality might well go both ways: in individuals with these hypothesized underlying deficits, use of testosterone and presumably other AAS may shift the balance even further towards an increased sensitivity for reward and decreased sensitivity for threat or punishment, as suggested by both animal $[157,158]$ and human studies [159,160]. No studies, to our knowledge, have assessed the possible role of such deficits in individuals with AAS dependence, but this possibility would seem to deserve further investigation.

\section{CONCLUSIONS}

A growing literature of human and animal studies suggests that AAS dependence is a valid diagnostic entity, often associated with conduct disorder and other forms of substance abuse. The prevalence of AAS dependence may be rising, as increasing numbers of AAS users are growing old enough to have established a dependence pattern. The diagnosis of AAS dependence requires some modest adaptations of standard diagnostic criteria for substance dependence, because these criteria were designed primarily for acutely intoxicating drugs and are not suited optimally for cumulatively acting drugs such as AAS. However, as suggested above, such criteria can be adapted easily for the diagnosis of AAS dependence.

AAS dependence is arguably the only major form of world-wide substance dependence that remains largely unexplored. In particular, it remains unclear why some AAS users progress from more benign initial use to more malignant AAS dependence-and the observed overlap between AAS and opioids, in both men and animals, might possibly hold a key to this explanation. Understanding the nature and etiology of AAS dependence is a 
matter of growing public health importance, as individuals with dependence probably account for the great majority of the public health problems associated with AAS, including the cardiovascular, neuroendocrine and psychiatric complications of long-term AAS exposure [9]. With an improved understanding of AAS dependence, we may be able to identify more clearly those at risk and better able to develop appropriate treatment.

\section{Declarations of interest}

None.

\section{Acknowledgement}

Supported in part by NIDA Grant DA 016744 (to Drs Pope, Kanayama and Hudson) and NIDA Grant DA 12843 (to Dr Wood).

\section{References}

1. Pope H. G., Brower K. J. Anabolic-androgenic steroidrelated disorders. In: Sadock B., Sadock V., editors. Comprehensive Textbook of Psychiatry, 9th edn. Philadelphia, PA: Lippincott Williams \& Wilkins; 2009, p. 1419-31.

2. Kouri E. M., Pope H. G. Jr, Katz D. L., Oliva P. Fat-free mass index in users and nonusers of anabolic-androgenic steroids. Clin J Sport Med 1995; 5: 223-8.

3. Wade N. Anabolic steroids: doctors denounce them, but athletes aren't listening. Science 1972; 176: 1399-403.

4. Hildebrandt T., Schlundt D., Langenbucher J., Chung T. Presence of muscle dysmorphia symptomology among male weightlifters. Compr Psychiatry 2006; 47: 127-35.

5. Buckley W. E., Yesalis C. E. III, Friedl K. E., Anderson W. A., Streit A. L., Wright J. E. Estimated prevalence of anabolic steroid use among male high school seniors. JAMA 1988; 260: 3441-5.

6. Kanayama G., Pope H. G. Jr, Hudson J. I. 'Body image' drugs: a growing psychosomatic problem. Psychother Psychosom 2001; 70: 61-5.

7. Parkinson A. B., Evans N. A. Anabolic androgenic steroids: a survey of 500 users. Med Sci Sports Exerc 2006; 38: 644-51.

8. Kanayama G., Hudson J. I., Pope H. G. Demographic and psychiatric features of men with anabolic-androgenic steroid dependence: a comparative study. Drug Alcohol Depend 2009; 102: 130-7.

9. Kanayama G., Hudson J. I., Pope H. G. Jr. Long-term psychiatric and medical consequences of anabolicandrogenic steroid abuse: a looming public health concern? Drug Alcohol Depend 2008; 98: 1-12.

10. Duchaine D. The Original Underground Steroid Handbook. Santa Monica, CA: OEM Publishing; 1981.

11. Duchaine D. Underground Steroid Handbook. Santa Monica, CA: OEM Publishing; 1983.

12. Duchaine D. Underground Steroid Handbook II. Los Angeles, CA: HLR Technical Books; 1988.

13. Phillips W. Anabolic Reference Guide. Golden, CO: Mile High Publishing; 1985.

14. Phillips W. Anabolic Reference Update. Golden, CO: Mile High Publishing; 1991.

15. Leit R. A., Pope H. G. Jr, Gray J. J. Cultural expectations of muscularity in men: the evolution of Playgirl centerfolds. Int J Eat Disord 2001; 29: 90-3.

16. Pope H. G. Jr, Phillips K. A., Olivardia R. The Adonis Complex: The Secret Crisis of Male Body Obsession. New York: Simon \& Schuster; 2000.

17. Pope H. G. Jr, Gruber A. J., Choi P., Olivardia R., Phillips KA. Muscle dysmorphia. An underrecognized form of body dysmorphic disorder. Psychosomatics 1997; 38: 54857.

18. Pope H. G. Jr, Olivardia R., Borowiecki J. J. III, Cohane G. H. The growing commercial value of the male body: a longitudinal survey of advertising in women's magazines. Psychother Psychosom 2001; 70: 189-92.

19. Pope H. G. Jr, Olivardia R., Gruber A. J., Borowiecki J. Evolving ideals of male body image as seen through action toys. Int J Eat Disord 1999; 26: 65-72.

20. Centers for Disease Control and Prevention (CDC); United States Department of Health and Human Services. Youth risk behavior surveillance-United States, 2007. MMWR 2008; 57 (SS-4). Available at: http://www.cdc.gov/ HealthyYouth/yrbs/pdf/yrbss07_mmwr.pdf (accessed 8 August 2009).

21. Johnston L. D., O’Malley P. M., Bachman J. G., Schulenberg J. E. Monitoring the Future National Survey Results on Drug Use, 1975-2005. Volume II: College Students and Adults Ages 19-45. NIH Publication no. 06-5884. Bethesda, MD: National Institute on Drug Abuse; 2006.

22. McCabe S. E., Brower K. J., West B. T., Nelson T. F., Wechsler H. Trends in non-medical use of anabolic steroids by U.S. college students: results from four national surveys. Drug Alcohol Depend 2007; 90: 243-51.

23. Handelsman D. J., Gupta L. Prevalence and risk factors for anabolic-androgenic steroid abuse in Australian high school students. Int J Androl 1997; 20: 159-64.

24. Melia P., Pipe A., Greenberg L. The use of anabolicandrogenic steroids by Canadian students. Clin J Sport Med 1996; 6: 9-14.

25. Kokkevi A., Fotiou A., Chileva A., Nociar A., Miller P. Daily exercise and anabolic steroids use in adolescents: a crossnational European study. Subst Use Misuse 2008; 43: 2053-65.

26. Thiblin I., Petersson A. Pharmacoepidemiology of anabolic androgenic steroids: a review. Fundam Clin Pharmacol 2005; 19: 27-44.

27. Nilsson S., Baigi A., Marklund B., Fridlund B. The prevalence of the use of androgenic anabolic steroids by adolescents in a county of Sweden. Eur J Public Health 2001; 11: 195-7.

28. Pallesen S., Josendal O., Johnsen B. H., Larsen S., Molde H. Anabolic steroid use in high school students. Subst Use Misuse 2006; 41: 1705-17.

29. Galduroz J. C., Noto A. R., Nappo S. A., Carlini E. A. Household survey on drug abuse in Brazil: study involving the 107 major cities of the country-2001. Addict Behav 2005; 30: 545-56.

30. Rachon D., Pokrywka L., Suchecka-Rachon K. Prevalence and risk factors of anabolic-androgenic steroids (AAS) abuse among adolescents and young adults in Poland. Soz Praventivmed 2006; 51: 392-8.

31. Wanjek B., Rosendahl J., Strauss B., Gabriel H. H. Doping, drugs and drug abuse among adolescents in the State of Thuringia (Germany): prevalence, knowledge and attitudes. Int J Sports Med 2007; 28: 346-53.

32. Pope H. G. Jr. Widespread anabolic steroid use in American 
girls and women: an illusion? Testimony before the United States House of Representatives Committee on Government Reform. Washington, DC, 15 June 2005.

33. Gruber A. J., Pope H. G. Jr. Psychiatric and medical effects of anabolic-androgenic steroid use in women. Psychother Psychosom 2000; 69: 19-26.

34. Malarkey W. B., Strauss R. H., Leizman D. J., Liggett M., Demers L. M. Endocrine effects in female weight lifters who self-administer testosterone and anabolic steroids. Am J Obstet Gynecol 1991; 165: 1385-90.

35. Kanayama G., Boynes M., Hudson J. I., Field A. E., Pope H. G. Jr. Anabolic steroid abuse among teenage girls: an illusory problem? Drug Alcohol Depend 2007; 88: 15662.

36. Kanayama G., Pope H. G. Jr, Cohane G., Hudson J. I. Risk factors for anabolic-androgenic steroid use among weightlifters: a case-control study. Drug Alcohol Depend 2003; 71: 77-86.

37. Pope H. G. Jr, Katz D. L. Psychiatric and medical effects of anabolic-androgenic steroid use. A controlled study of 160 athletes. Arch Gen Psychiatry 1994; 51: 37582.

38. Summers J. Steroids 101. Aurora, CO: Anabolics.com; 2003.

39. Reyes-Fuentes A., Veldhuis J. D. Neuroendocrine physiology of the normal male gonadal axis. Endocrinol Metab Clin North Am 1993; 22: 93-124.

40. Swerdloff R. S., Wang C., Hikim A. P. S. Hypothalamicpituitary-gonadal axis in men. In: Pfaff D., Arnold A., Etgen A., Fahrbach S., Rubin R., editors. Hormones, Brain and Behavior, vol. 5. San Diego, CA: Elsevier; 2002, p. $1-36$.

41. Cohen J., Collins R., Darkes J., Gwartney D. A league of their own: demographics, motivations and patterns of use of 1,955 male adult non-medical anabolic steroid users in the United States. J Int Soc Sports Nutr 2007; 4: 12.

42. Collins R. Legal Muscle: Anabolics in America. East Meadow, NY: Legal Muscle Publishing; 2002.

43. Brower K. J. Anabolic steroid abuse and dependence. Curr Psychiatry Rep 2002; 4: 377-87.

44. Basaria S., Wahlstrom J. T., Dobs A. S. Clinical review 138: anabolic-androgenic steroid therapy in the treatment of chronic diseases. J Clin Endocrinol Metab 2001; 86: 510817.

45. Tennant F., Black D. L., Voy R. O. Anabolic steroid dependence with opioid-type features. N Engl J Med 1988; 319: 578.

46. Brower K. J., Blow F. C., Beresford T. P., Fuelling C. Anabolic-androgenic steroid dependence. J Clin Psychiatry 1989; 50: 31-3.

47. Hays L. R., Littleton S., Stillner V. Anabolic steroid dependence. Am J Psychiatry 1990; 147: 122.

48. Brower K. J., Eliopulos G. A., Blow F. C., Catlin D. H., Beresford T. P. Evidence for physical and psychological dependence on anabolic androgenic steroids in eight weight lifters. Am J Psychiatry 1990; 147: 510-2.

49. American Psychiatric Association. Diagnostic and Statistical Manual of Mental Disorders, 3rd edn, revised. Washington, DC: American Psychiatric Association; 1987.

50. Brower K. J., Blow F. C., Young J. P., Hill E. M. Symptoms and correlates of anabolic-androgenic steroid dependence. Br J Addict 1991; 86: 759-68.

51. Copeland J., Peters R., Dillon P. Anabolic-androgenic steroid use disorders among a sample of Australian competitive and recreational users. Drug Alcohol Depend 2000; 60: 91-6.

52. Midgley S. J., Heather N., Davies J. B. Dependenceproducing potential of anabolic-androgenic steroids. Addict Res 1999; 7: 539-50.

53. Gridley D. W., Hanrahan S. J. Anabolic-androgenic steroid use among male gymnasium participants: knowledge and motives. Sports Health 1994; 12: 11-4.

54. Perry P. J., Lund B. C., Deninger M. J., Kutscher E. C., Schneider J. Anabolic steroid use in weightlifters and bodybuilders: an internet survey of drug utilization. Clin J Sport Med 2005; 15: 326-30.

55. American Psychiatric Association. Diagnostic and Statistical Manual of Mental Disorders, 4th edn. (DSM-IV). Washington, DC: American Psychiatric Association; 1994.

56. Spitzer R., Williams J., Gibbon M. Structured Clinical Interview for DSM-III-R (SCID). New York: New York State Psychiatric Institute; 1989.

57. Malone D. A. Jr, Dimeff R. J., Lombardo J. A., Sample R. H. Psychiatric effects and psychoactive substance use in anabolic-androgenic steroid users. Clin J Sport Med 1995; 5: 25-31.

58. Larance B., Degenhardt L., Copeland J., Dillon P. Injecting risk behaviour and related harm among men who use performance- and image-enhancing drugs. Drug Alcohol Rev 2008; 27: 679-86.

59. Pope H. G. Jr, Katz D. L. Psychiatric effects of exogenous anabolic-androgenic steroids. In: Wolkowitz O. M., Rothschild A. J., editors. Psychoneuroendocrinology: The Scientific Basis of Clinical Practice. Washington, DC: American Psychiatric Press; 2003, p. 331-58.

60. Johnson M. D., Jay M. S., Shoup B., Rickert V. I. Anabolic steroid use by male adolescents. Pediatrics 1989; 83: 921-4.

61. Bahrke M. S., Yesalis C. E., Brower K. J. Anabolicandrogenic steroid abuse and performance-enhancing drugs among adolescents. Child Adolesc Psychiatr Clin N Am 1998; 7: 821-38.

62. DuRant R. H., Rickert V. I., Ashworth C. S., Newman C., Slavens G. Use of multiple drugs among adolescents who use anabolic steroids. N Engl J Med 1993; 328: 922-6.

63. Middleman A. B., Faulkner A. H., Woods E. R., Emans S. J., DuRant R. H. High-risk behaviors among high school students in Massachusetts who use anabolic steroids. Pediatrics 1995; 96: 268-72.

64. Scott D. M., Wagner J. C., Barlow T. W. Anabolic steroid use among adolescents in Nebraska schools. Am J Health Syst Pharm 1996; 53: 2068-72.

65. Kashkin K. B., Kleber H. D. Hooked on hormones? An anabolic steroid addiction hypothesis. JAMA 1989; 262: 3166-70.

66. Arvary D., Pope H. G. Jr. Anabolic-androgenic steroids as a gateway to opioid dependence. $N$ Engl J Med 2000; 342: 1532 .

67. McBride A. J., Williamson K., Petersen T. Three cases of nalbuphine hydrochloride dependence associated with anabolic steroid use. Br J Sports Med 1996; 30: 69-70.

68. Wines J. D. Jr, Gruber A. J., Pope H. G. Jr, Lukas S. E. Nalbuphine hydrochloride dependence in anabolic steroid users. Am J Addict 1999; 8: 161-4.

69. Kanayama G., Cohane G. H., Weiss R. D., Pope H. G. Past anabolic-androgenic steroid use among men admitted for substance abuse treatment: an underrecognized problem? J Clin Psychiatry 2003; 64: 156-60. 
70. Thiblin I., Lindquist O., Rajs J. Cause and manner of death among users of anabolic-androgenic steroids. J Forensic Sci 2000; 45: 16-23.

71. Wood R. I. Anabolic-androgenic steroid dependence? Insights from animals and humans. Front Neuroendocrinol 2008; 29: 490-506.

72. Alexander G. M., Packard M. G., Hines M. Testosterone has rewarding affective properties in male rats: implications for the biological basis of sexual motivation. Behav Neurosci 1994; 108: 424-8.

73. Arnedo M. T., Salvador A., Martinez-Sanchis S., GonzalezBono E. Rewarding properties of testosterone in intact male mice: a pilot study. Pharmacol Biochem Behav 2000; 65: 327-32.

74. Wood R. I. Anabolic steroids: a fatal attraction? J Neuroendocrinol 2006; 18: 227-8.

75. Peters K. D., Wood R. I. Androgen dependence in hamsters: overdose, tolerance, and potential opioidergic mechanisms. Neuroscience 2005; 130: 971-81.

76. Foltin R. W. The importance of drug self-administration studies in the analysis of abuse liability: an analysis of caffeine, nicotine, anabolic steroids, and designer drugs. Am J Addict 1992; 1: 139-49.

77. Johansson P., Ray A., Zhou Q., Huang W., Karlsson K., Nyberg F. Anabolic androgenic steroids increase betaendorphin levels in the ventral tegmental area in the male rat brain. Neurosci Res 1997; 27: 185-9.

78. Johansson P., Lindqvist A., Nyberg F., Fahlke C. Anabolic androgenic steroids affects alcohol intake, defensive behaviors and brain opioid peptides in the rat. Pharmacol Biochem Behav 2000; 67: 271-9.

79. Harlan R. E., Brown H. E., Lynch C. S., D’Souza D., Garcia M. M. Androgenic-anabolic steroids blunt morphineinduced c-fos expression in the rat striatum: possible role of beta-endorphin. Brain Res 2000; 853: 99-104.

80. Celerier E., Yazdi M. T., Castane A., Ghozland S., Nyberg F., Maldonado R. Effects of nandrolone on acute morphine responses, tolerance and dependence in mice. Eur J Pharmacol 2003; 465: 69-81.

81. Knoll A. T., Meloni E. G., Thomas J. B., Carroll F. I., Carlezon W. A. Jr. Anxiolytic-like effects of kappa-opioid receptor antagonists in models of unlearned and learned fear in rats. J Pharmacol Exp Ther 2007; 323: 838-45.

82. Newton S. S., Thome J., Wallace T. L., Shirayama Y., Schlesinger L., Sakai N. et al. Inhibition of cAMP response element-binding protein or dynorphin in the nucleus accumbens produces an antidepressant-like effect. J Neurosci 2002; 22: 10883-90.

83. Agren G., Thiblin I., Tirassa P., Lundeberg T., Stenfors C. Behavioural anxiolytic effects of low-dose anabolic androgenic steroid treatment in rats. Physiol Behav 1999; 66: 503-9.

84. Triemstra J. L., Sato S. M., Wood R. I. Testosterone and nucleus accumbens dopamine in the male Syrian hamster. Psychoneuroendocrinology 2008; 33: 386-94.

85. Negus S. S., Pope H. G. Jr, Kanayama G., Wines J. D. Jr, Fischer B. D. Lack of evidence for opioid tolerance or dependence in Rhesus monkeys following high-dose anabolic-androgenic steroid administration. Psychoneuroendocrinology 2001; 26: 789-96.

86. Daly R. C., Su T. P., Schmidt P. J., Pickar D., Murphy D. L., Rubinow D. R. Cerebrospinal fluid and behavioral changes after methyltestosterone administration: preliminary findings. Arch Gen Psychiatry 2001; 58: 172-7.
87. Lindqvist A. S., Johansson-Steensland P., Nyberg F., Fahlke C. Anabolic androgenic steroid affects competitive behaviour, behavioural response to ethanol and brain serotonin levels. Behav Brain Res 2002; 133: 21-9.

88. Ricci L. A., Rasakham K., Grimes J. M., Melloni R. H. Jr. Serotonin-1A receptor activity and expression modulate adolescent anabolic/androgenic steroid-induced aggression in hamsters. Pharmacol Biochem Behav 2006; 85: $1-11$.

89. Tamaki T., Shiraishi T., Takeda H., Matsumiya T., Roy R. R., Edgerton V. R. Nandrolone decanoate enhances hypothalamic biogenic amines in rats. Med Sci Sports Exerc 2003; 35: 32-8.

90. Kurling S., Kankaanpaa A., Ellermaa S., Karila T., Seppala T. The effect of sub-chronic nandrolone decanoate treatment on dopaminergic and serotonergic neuronal systems in the brains of rats. Brain Res 2005; 1044: 67-75.

91. Schwartzer J. J., Ricci L. A., Melloni R. H. Jr. Adolescent anabolic-androgenic steroid exposure alters lateral anterior hypothalamic serotonin-2A receptors in aggressive male hamsters. Behav Brain Res 2009; 199: 257-62.

92. Thiblin I., Finn A., Ross S. B., Stenfors C. Increased dopaminergic and 5-hydroxytryptaminergic activities in male rat brain following long-term treatment with anabolic androgenic steroids. Br J Pharmacol 1999; 126: 13016.

93. Frye C. A. Some rewarding effects of androgens may be mediated by actions of its 5alpha-reduced metabolite 3alpha-androstanediol. Pharmacol Biochem Behav 2007; 86: 354-67.

94. Kindlundh A. M., Lindblom J., Bergstrom L., Nyberg F. The anabolic-androgenic steroid nandrolone induces alterations in the density of serotonergic 5HT1B and 5HT2 receptors in the male rat brain. Neuroscience 2003; 119: 113-20.

95. Kindlundh A. M., Rahman S., Lindblom J., Nyberg F. Increased dopamine transporter density in the male rat brain following chronic nandrolone decanoate administration. Neurosci Lett 2004; 356: 131-4.

96. Schroeder J. P., Packard M. G. Role of dopamine receptor subtypes in the acquisition of a testosterone conditioned place preference in rats. Neurosci Lett 2000; 282: 17-20.

97. Birgner C., Kindlundh-Hogberg A. M., Alsio J., Lindblom J., Schioth H. B., Bergstrom L. The anabolic androgenic steroid nandrolone decanoate affects mRNA expression of dopaminergic but not serotonergic receptors. Brain Res 2008; 1240: 221-8.

98. Kindlundh A. M., Bergstrom M., Monazzam A., Hallberg M., Blomqvist G., Langstrom B. et al. Dopaminergic effects after chronic treatment with nandrolone visualized in rat brain by positron emission tomography. Prog Neuropsychopharmacol Biol Psychiatry 2002; 26: 1303-8.

99. Ricci L. A., Schwartzer J. J., Melloni R. H. Jr. Alterations in the anterior hypothalamic dopamine system in aggressive adolescent AAS-treated hamsters. Horm Behav 2009; 55: 348-55.

100. Schwartzer J. J., Ricci L. A., Melloni R. H. Jr. Interactions between the dopaminergic and GABAergic neural systems in the lateral anterior hypothalamus of aggressive AAStreated hamsters. Behav Brain Res 2009.

101. Wood R. I. Reinforcing aspects of androgens. Physiol Behav 2004; 83: 279-89.

102. Henderson L. P. Steroid modulation of GABAA receptormediated transmission in the hypothalamus: effects 
on reproductive function. Neuropharmacology 2007; 52: 1439-53.

103. Henderson L. P., Penatti C. A., Jones B. L., Yang P., Clark A. S. Anabolic androgenic steroids and forebrain GABAergic transmission. Neuroscience 2006; 138: 793-9.

104. Kurling S., Kankaanpaa A., Seppala T. Sub-chronic nandrolone treatment modifies neurochemical and behavioral effects of amphetamine and 3,4-methylenedioxymethamphetamine (MDMA) in rats. Behav Brain Res 2008; 189 : 191-201.

105. Célérier E., Ahdepil T., Wikander H., Berrendero F., Nyberg F., Maldonado R. Influence of the anabolic-androgenic steroid nandrolone on cannabinoid dependence. Neuropharmacology 2006; 50: 788-806.

106. Hochberg Z., Pacak K., Chrousos G. P. Endocrine withdrawal syndromes. Endocr Rev 2003; 24: 523-38.

107. Bahrke M. S., Yesalis C. E., Kopstein A. N., Stephens J. A. Risk factors associated with anabolic-androgenic steroid use among adolescents. Sports Med 2000; 29: 397-405.

108. Kindlundh A. M., Hagekull B., Isacson D. G., Nyberg F. Adolescent use of anabolic-androgenic steroids and relations to self-reports of social, personality and health aspects. Eur J Public Health 2001; 11: 322-8.

109. Kindlundh A. M., Isacson D. G., Berglund L., Nyberg F. Factors associated with adolescent use of doping agents: anabolic-androgenic steroids. Addiction 1999; 94: 54353.

110. Nilsson S., Spak F., Marklund B., Baigi A., Allebeck P. Attitudes and behaviors with regards to androgenic anabolic steroids among male adolescents in a county of Sweden. Subst Use Misuse 2004; 39: 1183-97.

111. Yesalis C. E., Bahrke M. S. Anabolic-androgenic steroids and related substances. Curr Sports Med Rep 2002; 1: 24652.

112. Fingerhood M. I., Sullivan J. T., Testa M., Jasinski D. R. Abuse liability of testosterone. J Psychopharmacol 1997; 11: 59-63.

113. Pope H. G., Brower K. J. Treatment of anabolic-androgenic steroid-related disorders. In: Galanter M., Kleber H., editors. The American Psychiatric Publishing Textbook of Substance Abuse Treatment, 4th edn. Washington, DC: American Psychiatric Publishing; 2008, p. 237-46.

114. Pope H. G., Kanayama G., Ionescu-Pioggia M., Hudson J. I. Anabolic steroid users' attitudes towards physicians. Addiction 2004; 99: 1189-94.

115. Dawson R. Drugs in sport-the role of the physician. J Endocrinol 2001; 170: 55-61.

116. Kutscher E. C., Lund B. C., Perry P. J. Anabolic steroids: a review for the clinician. Sports Med 2002; 32: 285-96.

117. World Health Organization. The International Classification of Diseases and Health-Related Problems (ICD-10), 2nd edn. Geneva: World Health Organization; 2005.

118. Kanayama G., Brower K. J., Wood R. I., Hudson J. I., Pope H. G. Jr. Issues for DSM-V: clarifying the diagnostic criteria for anabolic-androgenic steroid dependence. Am J Psychiatry 2009; 166: 642-4.

119. Hughes J. Should criteria for drug dependence differ across drugs? In: Saunders J., Schuckit M., Sirovatka P., Regier D., editors. Diagnostic Issues in Substance Use Disorders: Refining the Research Agenda for DSM-V. Arlington, VA: American Psychiatric Association, 2007, p. 237-50.

120. United States Drug Enforcement Administration. United States Code Title 21; Controlled Substances Act; Section 812: Schedules of Controlled Substances. 2008.
Available at: http://www.usdoj.gov/dea/pubs/csa/812. htm (accessed 8 August 2009).

121. United States Drug Enforcement Administration. DEA announces largest steroid enforcement action in U.S. history. 2007. Available at: http://www.usdoj.gov/dea/ pubs/pressrel/pr092407.html (accessed 8 August 2009).

122. Choi P. Y., Pope H. G. Jr, Olivardia R. Muscle dysmorphia: a new syndrome in weightlifters. Br J Sports Med 2002; 36: 375-6; discussion 377.

123. Kanayama G., Barry S., Hudson J. I., Pope H. G. Jr. Body image and attitudes toward male roles in anabolicandrogenic steroid users. Am J Psychiatry 2006; 163: 697-703.

124. Olivardia R., Pope H. G. Jr, Hudson J. I. Muscle dysmorphia in male weightlifters: a case-control study. Am J Psychiatry 2000; 157: 1291-6.

125. Pope C. G., Pope H. G., Menard W., Fay C., Olivardia R., Phillips K. A. Clinical features of muscle dysmorphia among males with body dysmorphic disorder. Body Image 2005; 2: 395-400.

126. Cole J. C., Smith R., Halford J. C., Wagstaff G. F. A preliminary investigation into the relationship between anabolicandrogenic steroid use and the symptoms of reverse anorexia in both current and ex-users. Psychopharmacology (Berl) 2003; 166: 424-9.

127. Schwerin M. J., Corcoran K. J., Fisher L., Patterson D., Askew W., Olrich T. et al. Social physique anxiety, body esteem, and social anxiety in bodybuilders and selfreported anabolic steroid users. Addict Behav 1996; 21: $1-8$.

128. Chung B. Muscle dysmorphia in weightlifters. $\mathrm{Br} J$ Sports Med 2003; 37: 280-1.

129. Cafri G., Thompson J. K., Ricciardelli L., McCabe M., Smolak L., Yesalis C. Pursuit of the muscular ideal: physical and psychological consequences and putative risk factors. Clin Psychol Rev 2005; 25: 21539.

130. Boyadjiev N. P., Georgieva K. N., Massaldjieva R. I., Gueorguiev S. I. Reversible hypogonadism and azoospermia as a result of anabolic-androgenic steroid use in a bodybuilder with personality disorder. A case report. J Sports Med Phys Fitness 2000; 40: 271-4.

131. Brower K. J. Withdrawal from anabolic steroids. Curr Ther Endocrinol Metab 1997; 6: 338-43.

132. Malone D. A. Jr, Dimeff R. J. The use of fluoxetine in depression associated with anabolic steroid withdrawal: a case series. J Clin Psychiatry 1992; 53: 130-2.

133. Reynolds B. A review of delay-discounting research with humans: relations to drug use and gambling. Behav Pharmacol 2006; 17: 651-67.

134. Bickel W. K., Marsch L. A. Towards a behavioral economic understanding of drug dependence: delay discounting processes. Addiction 2001; 96: 73-86.

135. Verdejo-Garcia A., Lawrence A. J., Clark L. Impulsivity as a vulnerability marker for substance-use disorders: review of findings from high-risk research, problem gamblers and genetic association studies. Neurosci Biobehav Rev 2008; 32: $777-810$.

136. de Wit H. Impulsivity as a determinant and consequence of drug use: a review of underlying processes. Addict Biol 2008.

137. Perry J. L., Carroll M. E. The role of impulsive behavior in drug abuse. Psychopharmacology (Berl) 2008; 200: $1-26$. 
138. Bechara A. Decision making, impulse control and loss of willpower to resist drugs: a neurocognitive perspective. Nat Neurosci 2005; 8: 1458-63.

139. Rogers R. D., Robbins T. W. Investigating the neurocognitive deficits associated with chronic drug misuse. Curr Opin Neurobiol 2001; 11: 250-7.

140. Dom G., Sabbe B., Hulstijn W., van den Brink W. Substance use disorders and the orbitofrontal cortex: systematic review of behavioural decision-making and neuroimaging studies. Br J Psychiatry 2005; 187: 209-20.

141. van Honk J., Hermans E. J., Putman P., Montagne B., Schutter D. J. Defective somatic markers in sub-clinical psychopathy. Neuroreport 2002; 13: 1025-7.

142. Mazas C. A., Finn P. R., Steinmetz J. E. Decision-making biases, antisocial personality, and early-onset alcoholism. Alcohol Clin Exp Res 2000; 24: 1036-40.

143. Vassileva J., Gonzalez R., Bechara A., Martin E. M. Are all drug addicts impulsive? Effects of antisociality and extent of multidrug use on cognitive and motor impulsivity. Addict Behav 2007; 32: 3071-6.

144. Petry N. M. Discounting of delayed rewards in substance abusers: relationship to antisocial personality disorder. Psychopharmacology (Berl) 2002; 162: 425-32.

145. Kim Y. T., Lee S. J., Kim S. H. Effects of the history of conduct disorder on the Iowa Gambling Tasks. Alcohol Clin Exp Res 2006; 30: 466-72.

146. Ernst M., Grant S. J., London E. D., Contoreggi C. S., Kimes A. S., Spurgeon L. Decision making in adolescents with behavior disorders and adults with substance abuse. Am J Psychiatry 2003; 160: 33-40.

147. Blair R. J., Colledge E., Mitchell D. G. Somatic markers and response reversal: is there orbitofrontal cortex dysfunction in boys with psychopathic tendencies? J Abnorm Child Psychol 2001; 29: 499-511.

148. Cooper C. J., Noakes T. D., Dunne T., Lambert M. I., Rochford K. A high prevalence of abnormal personality traits in chronic users of anabolic-androgenic steroids. $\mathrm{Br} J$ Sports Med 1996; 30: 246-50.

149. Klotz F., Garle M., Granath F., Thiblin I. Criminality among individuals testing positive for the presence of anabolic androgenic steroids. Arch Gen Psychiatry 2006; 63: 1274-9.

150. Klotz F., Petersson A., Isacson D., Thiblin I. Violent crime and substance abuse: a medico-legal comparison between deceased users of anabolic androgenic steroids and abusers of illicit drugs. Forensic Sci Int 2007.

151. Perry P. J., Kutscher E. C., Lund B. C., Yates W. R., Holman T. L., Demers L. Measures of aggression and mood changes in male weightlifters with and without androgenic anabolic steroid use. J Forensic Sci 2003; 48: 646-51.

152. Porcerelli J. H., Sandler B. A. Narcissism and empathy in steroid users. Am J Psychiatry 1995; 152: 1672-4.

153. Thiblin I., Kristiansson M., Rajs J. Anabolic androgenic steroids and behavioural patterns among violent offenders. J Forensic Psychiatry 1997; 8: 299-310.

154. Thiblin I., Parlklo T. Anabolic androgenic steroids and violence. Acta Psychiatr Scand Suppl 2002; 412: 125-8.

155. Yates W. R., Perry P. J., Andersen K. H. Illicit anabolic steroid use: a controlled personality study. Acta Psychiatr Scand 1990; 81: 548-50.

156. Gottesman I. I., Gould T. D. The endophenotype concept in psychiatry: etymology and strategic intentions. $A m$ J Psychiatry 2003; 160: 636-45.

157. Bing O., Heilig M., Kakoulidis P., Sundblad C., Wiklund L., Eriksson E. High doses of testosterone increase anticonflict behaviour in rat. Eur Neuropsychopharmacol 1998; 8: 321-3.

158. Boissy A., Bouissou M. F. Effects of androgen treatment on behavioral and physiological responses of heifers to fear-eliciting situations. Horm Behav 1994; 28: 66-83.

159. Hermans E. J., Putman P., Baas J. M., Gecks N. M., Kenemans J. L., van Honk J. Exogenous testosterone attenuates the integrated central stress response in healthy young women. Psychoneuroendocrinology 2007; 32: 1052-61.

160. van Honk J., Schutter D. J., Hermans E. J., Putman P., Tuiten A., Koppeschaar H. Testosterone shifts the balance between sensitivity for punishment and reward in healthy young women. Psychoneuroendocrinology 2004; 29: $937-$ 43. 